\title{
ПАРТНЕРСТВО ЯК МОДЕЛЬ ВЗАЕМОДІї ДЕРЖАВИ Й ГРОМАДЯНСЬКОГО СУСПІЛЬСТВА
}

\author{
АНІСІМОВ Кирило Ігорович - заступник начальника Управління \\ організаційно-аналітичного забезпечення та оперативного реагування ГУНП в \\ Запорізькій області
}

DOI 10.32782/NP.2021.2.16

\begin{abstract}
В статье проанализирована сущность партнерства как основополагающей модели взаимодействия государства и гражданского общества. Охарактеризован механизм партнерских отношений между полищией и территориальньли обшинами. Констатировано, что постоянная трансбормация смвисловой нагрузки идеи гражданского общества осуществила влияние на особенности представлений об идеальной модели общественного устройства и спещифику сощиально-экономической бормации на конкретном этапе развития человечества. Уяснено понимание сущности гражданского общества и ощенка перспектив его влияния на развитие человеческой организации. Установлено, что сущзость партнерских отношений между органами государственной власти и территориальнълми общинами обусловлена их существованием в качестве сложного прочесса, которьй предусматривает реализачию механизмов взаимного контроля и ограничений. Государство в указанном процессе въиступает в качестве субъекта, не только наделенного властнылм полномочиями, но и способного делегировать их институтам гражданского общества, путем наделения территориальньх общин соответствующей компетеницей. Доказано, что механизм партнерских отношений между государством и территориальньлм общинами должен предусматривать реализаиию следующих мероприятий: а) осуществление правотворческой деятельности органов государственной власти; б) принятие нормативньих правовылх актов, с целью поддержки и развития институтов гражданского общества; в) налаживание действенного диалога органов государственной власти и инсти-
\end{abstract}

тутов гражданского общества; г) готовность государства использовать общественньий контроль для устранения недостатков; д) участие институтов гражданского общества в ребормировании системъ государственной власти, обучении и воспитании чиновников государственньхх структур.

Ключевъге слова: партнерство, взаимодействие, гражданское общество, партнерские отношения, полищия, территориальнъие общинъи, органъи государственной власти, контроль, властнье полномочия, компетениия, правотворческая деятельность, общественнье организации, нормативно-правовой акт.

\section{Обгрунтування вибору теми дослідження}

Організація взаємодії інститутів громадянського суспільства та держави посідає центральне місце в сучасній системі публічного управління. Недостатня ефективність діяльності органів публічної адміністрації, як правило, пов'язана із браком дієвої комунікації із населенням, відсутністю реальних механізмів взаємодії з місцевою громадою.

Співіснування держави та інститутів громадянського суспільства $є$ складниу процесом взаємного контролю та правообмежень, у якому держава, виступаючи як суб'єкт, наділений владними повноваженнями, запроваджує легальний механізм втручання у власну діяльність, шляхом участі інститутів громадянського суспільства в реалізації державних функцій та контролі функціонування державного механізму. 


\section{Адміністративне право}

Процес реформування системи інститутів публічної влади передбачає суттєву активізацію участі в його здійсненні інститутів громадянського суспільства на всіх рівнях. При цьому має відбуватися поступова зміна типу соціальних відносин між владою і громадськістю - $з$ відносин підпорядкування на відносини діалогу та партнерства. Така співпраця повинна грунтуватись на конструктивних, функціональних засадах, що, у свою чергу, актуалізує потребу у виробленні дієвої системи заходів і механізмів взаємодії органів державної влади, місцевого самоврядування, бізнесу та інститутів громадянського суспільства 3 метою вдосконалення соціальної системи відповідно до публічних інтересів.

У контексті розбудови демократичної, соціальної і правової держави окреслена проблематика набуває особливої актуальності i 6 предметом численних наукових досліджень.

\section{Стан дослідження}

3'ясування сутності партнерства, як основоположної моделі взаємодії держави й громадянського суспільства висвітлено у наукових працях С.С. Алексеєва, В.М. Бесчастного, Т. Дж. Бойєра, О.В. Венцика, С.О. Кириченка, Ф. Клівера, В.В. Костицького, Д. Аьюїса, Р.В. Маккуейда, С.П. Осборна, О.В. Тимченка, Р. Чемберса, О. Чикаренка.

Разом $з$ тим, потребує додаткового уточнення адміністративно-правова характеристика механізмів взаємодії поліції й територіальних громад на засадах партнерства.

Мета дослідження полягає в тому, щоб на основі аналізу теоретичних напрацювань у галузі адміністративного права та інших галузей правової науки з'ясувати сутність партнерства, як основоположної моделі взаємодії держави й громадянського суспільства та охарактеризувати механізм партнерських відносин між поліцією та територіальними громадами.

\section{Виклад основних положень}

Незважаючи на існування у сучасній правовій науці різних типів праворозуміння, наявності різноманітних підходів щодо з'ясування сутності держави й державного управління, дуалістична правова конструкція «правова держава - громадянське суспільство» знаходить відображення у багатьох теоретичних напрацюваннях. У процесі співвідношення двох вищевказаних явищ С.О. Кириченко доходить висновку про відсутність тотожності у їх розумінні. «Хоча деякі сутнісні ознаки громадянського суспільства і правової держави, на думку вченого, - збігаються, а також існує тісне переплетіння і органічний взаємозв' язок ïx інститутів, відповідні явища не тотожні. Держава, ... є інститутом громадянського суспільства, яке ії утворює; громадянське суспільство - це соціальний фундамент правової держави і одночасно відповідне середовище, в якому функціонує держава» [1, с. 14]. Таким чином, учений цілком справедливо визначає примат громадянського суспільства, підкреслюючи його ключову роль у формуванні правової держави.

С.С. Алексєєв, підкреслюючи позитивну роль правової системи держави, характеризує право в якості «суттєвого громадського блага», яке виступає виразником загальної й індивідуальної волі та різних інтересів учасників суспільних відносин, забезпечує стабільність та впорядкування соціальної системи [2, с. 16]. Уявляється, що в такому контексті правова держава тісно пов'язана із громадянським суспільством, яке виступає атрибутивною характеристикою та головною умовою їі формування.

Дійсно, у багатьох випадках розуміння правової держави не має самостійного походження, а може бути розкрито тільки через його взаємини із суспільством. Отже, з метою якнайширшого розкриття теми дослідження вважаємо за доцільне з'ясувати сутність партнерських відносин та визначити напрямки взаємодії, за яких держава та громадянське суспільство набувають правового статусу партнерів.

Сутність партнерства та його відмінні характеристики $є$ предметом прискіпливої уваги фахівців у галузі науки державного управління. Так, В.В. Костицький, надаючи відносинам між державою та громадянським суспільством політологічного забарвлення, до передумов виникнення партнерства між державою і суспільством відносить існування компетентної бюрократії, яка перетворюється у світовий (глобальний) клас добре забез- 
печених у матеріальному плані «білих» та «синіх» комірців [3].

У зарубіжній літературі партнерство розглядається в контексті форми організації та характеристики політичних інститутів. Зарубіжні дослідники, розглядаючи досліджуване явище, розуміють передовсім співпрацю, взаємну довіру і взаємодію між окремими особами і організаціями, необхідну для досягнення спільної мети. «Партнерство асоціюється із взаємодією двох або більше сторін, - підкреслює Р. В. Маккуейд, - діяльність яких спрямована на досягнення спільної мети шляхом об'єднання власних ресурсів» [4, с. 252]. У цьому контексті науковець акцентує увагу, скоріше, на необхідності досягнення спільної мети, підтриманні довіри між суб'єктами іiі реалізації, ніж на матеріальних перевагах та примушуванні. За справедливим судженням Д. Л'юїса, «партнерство, засноване на довірі, розкриває його сутність як тривалий процес, у результаті тривалих відносин між двома сторонами» [4, с. 259].

У зарубіжній теоретичній та практичній юриспруденції поняття «партнерство» часто зустрічається при характеристиці офіційних та політичних інститутів [5]. Партнерство може бути характерне для інституційних структур і управління. Партнерство закріплюється правилами, приписами та управлінськими діями там, де воно реально появляється [6].

Під час характеристики партнерських відносин між органами державного управління та територіальними громадами доцільно говорити про їх взаємодію, яка проявляється у взаємодоповнюваності діяльності обох суб'єктів. Принцип взаємодоповнюваності, за умови збереження примату основної владної управлінської структури, спрямований на вирішення конкретних соціальних проблем, успішне подолання яких підтверджується основною функцією партнерства, націленою на сприяння участі громади у прийнятті рішень, які стосуються іiі життєдіяльності [7, с. 56].У той же час, на думку Ф. Клівера, такий підхід не сприяе грунтовному аналізу владних відносин, якими реально наділена територіальна громада [8, с. 36].

Вказане твердження має дискусійний характер. 3 одного боку, вказана позиція знаходить підтвердження Т.Ж. Боуера, який акцен- тує увагу на недосконалому функціонуванні механізму партнерських відносин між територіальними громадами та органами державної влади, не зважаючи на постійні наміри законодавця гарантувати повну та активну участь суспільства в соціальних програмах [9, с. 178].

3 іншого боку, слід звернути увагу на судження вітчизняних науковців, які, загалом, позитивно оцінюють державну політику щодо децентралізації державного управління, а відтак - наділення територіальних громад реальними повноваженнями у взаємодії 3 державними інституціями, зокрема, з органами поліції, імідж яких, на думку професора B.M. Бесчастного, безпосередньо залежить від успішної взаємодії вищевказаних інститутів $[10$, с. 6$]$.

Зміст партнерських відносин між поліцією та територіальною громадою, на думку О.В. Венцика, проявляється у встановленні таких відносин між ними, «за яких вони разом розв’язують проблеми боротьби зі злочинністю та підтримання належного правопорядку за місцем проживання громадян». На думку автора, «спрацьовує один із основних принципів функціонування поліції: громадська безпека і правопорядок - спільна турбота держави й суспільства» [11, с. 18].

Слід також зауважити, що партнерські відносини поліції й територіальних громад, 3 визначенням повноважень суб'єктів вказаної діяльності, знайшли відображення й у законодавчих та підзаконних нормативно-правових актах [12-15], докладний аналіз яких буде проведено пізніше.

Таким чином, висновок про неефективність партнерства громадських інституцій та органів державної влади, на думку автора, має спірний характер. Аналогічну позицію висловлює й О. Чикаренко, який доходить висновку про зростаючу ефективність процесів децентралізації влади, результатом чого виступає стрімке збільшення кількості новостворених об'єднаних територіальних громад та розширення їх повноважень [16, с. 272]. Так, станом на серпень 2020 року в Україні створено 858 ОТГ, до складу яких включено 10587 населених пунктів, а саме: 3 міста обласного значення, 108 міст районного значення, 278 селищ міського типу, 9870 сіл та 328 селищ [17]. 


\section{Адміністративне право}

\section{Висновки}

Підбиваючи підсумки, слід зазначити, що держава на різних етапах свого існування завжди виконувала роль важливого, але не єдиного суб'єкта регулювання соціальних відносин у різних сферах суспільно-політичного життя. Численні спроби осмислення позадержавного управління суспільними процесами призвели до появи ідеї громадянського суспільства та вироблення відповідної дефініції. Постійна трансформація змістовного навантаження ідеї громадянського суспільства відображала особливості уявлень про ідеальні моделі суспільного устрою та специфіку соціально-економічної формації на конкретному етапі розвитку людства.

Розуміння сутності громадянського суспільства й оцінка перспектив його впливу на розвиток людської організації завжди відрізнялися різноманіттям. Сучасна вітчизняна та зарубіжна наука акумулювала різні підходи до розгляду громадянського суспільства. При цьому, яким би не був погляд на сутність і структуру громадянського суспільства, переважна більшість дослідників припускає наявність у громадянському суспільстві неурядових та некомерційних організацій - інститутів громадянського суспільства, які перебувають у взаємозв’ язку між собою та державою.

Сутність партнерських відносин між органами державної влади (в тому числі й правоохоронними органами) та територіальними громадами обумовлено їх існуванням в якості складного процесу, який передбачає реалізацію механізмів взаємного контролю та обмежень. Причому держава у вказаному процесі виступає як суб'єкт, не тільки наділений власними владними повноваженнями, а й здатний делегувати їх інститутам громадянського суспільства, шляхом наділення територіальних громад відповідною компетенцією.

Уявляється, що механізм партнерських відносин між державою та територіальними громадами повинен передбачати реалізацію наступних заходів: а) здійснення правотворчої діяльності органів державної влади, наслідком чого виступає утворення та розвиток незалежних громадських організацій як основи громадянського суспільства; б) прийняття нормативних правових актів 3 метою підтримки й розвитку інститутів громадян- ського суспільства; в) налагодження дієвого діалогу органів державної влади та інститутів громадянського суспільства у різних формах; г) готовність держави використовувати громадський контроль для усунення недоліків, визначення основних напрямків державноправового розвитку, виявлення ефективних механізмів вирішення суспільно важливих завдань; д) участь інститутів громадянського суспільства у реформуванні системи державної влади, навчанні й вихованні чиновників державних структур.

\section{Мiтература}

1. Кириченко С.О. Співвідношення соціальної правової держави і громадянського суспільства в умовах сучасної України: автореф. дис. ... канд. юрид. наук: 12.00.01 / Київський національний університет імені Тараса Шевченка. К., 2001. 18 с.

2. Алексеев, С. С. Право на пороге нового тысячелетия: Некоторые тенденции мирового правового развития - надежда и драма современной эпохи [Текст] / С. С. Алексеев. М. : Статут, 2000. - С. 15-19.

3. Костицький В.В. Партнерство правової держави і суспільства в умовах глобалізації. URL: http://dspace.nbuv.gov.ua/ bitstream/handle/123456789/39576/05-Kostickiy. pdf?sequence $=1$.

4. Lewis D. Building «active» partnership in aid-recipient countries: lessons from a rural development project in Bangladesh // Osborne S. P. Public-private partnerships: theory and practice in international perspective. P. 252-264.

5. Department for International Development. Programme Partnership Arrangements.London.DFID.2016.URL:https:// www.gov.uk/international-development-funding/ programme-partnershiparrangements.

6. World Bank. Public-private partnership. Washington: World Bank. 2016. URL: http://www. worldbank.org/en/topic/ publicprivatepartnerships.

7. Chambers R. Rural development: putting the last first. London: Routledge, 2014. P. 56.

8. Cleaver F. Institutions, agency and the limitations of participatory approaches to development // Cooke B. Kothari u. participation: the new tyranny? London: Zed books, 2001.P. 36. 


\section{АНОТАЦІЯ}

у статті проаналізовано сутність партнерства як основоположної моделі взаємодї держави й громадянсъкого суспільства. Охарактеризовано механізм партнерських відносин між поліиією та територіальними громадами. Констатовано, що постійна трансформащія змістовного навантаження ідеї громадянсъкого суспільства здійснила вплив на особливості уявлень про ідеальні моделі суспільного устрою та специббіку сочиально-економічної бормаизї на конкретному етапі розвитку людства. З’ясовано розуміння сутності громадянсъкого суспільства й оцінка перспектив його впливу на розвиток людської організаиій. Встановлено, що сутність партнерсъких відносин між органами державної влади та територіальними громадами обумовлено їх існуванням як складного прочесу, який передбачає реалізачію механізмів взаємного контролю та обмежень. Причому держава у вказаному процесі виступає в якості суб'єкта, не тільки наділений владними повноваженнями, а й здатний делегувати їх інститутам громадянсъкого суспільства, шляхом наділення територіальних громад відповідною компетениією.

Ключові слова: партнерство, взаємодія, громадянсъке суспільство, партнерсъкі відносини, поліиія, територіальні громади, органи державної влади, контроль, владні повноваження, компетениія, правотвориа діяльність, громадські організациї, нормативно-правовий акт.

9. Bowyer T. J. Popular participation and the state: democratising the health sector in rural Peru. Thesis (PhD). London: University of London, 2003. P. 178.

10. Бесчастний В. М. Імідж як складова успіху правоохоронця: до постановки проблеми. Віче. 2012. № 2. С. 6-8.

11. Венцик О.В. Складові оптимізації взаємодії поліції з населенням. Сучасні стратегії та перспективи оптимізациї взаємодї поліиіӥ і населення в соиіумі: матеріали круглого столу (23 листопада 2017 р.). - Аьвів: АьвДУВС, 2017. С. 17-19.

12. Про місцеве самоврядування: Закон України від 21.05.1997 № 280/97-ВР. Відомості Верховної Ради Украӥни. 1997. № 24. Ст. 170.

13. Про Національну поліцію: Закон України від 02.07.2015 № 580-VIII. Відомості Верховної Ради. 2015. № 40-41. Ст. 379.

\section{SUMMARY}

The article analyzes the essence of partnership as a fundamental model of interaction between the state and civil society. The mechanism of partnership relations between the police and territorial communities is described. It is stated that the constant transformation of the content of the idea of civil society has influenced the peculiarities of ideas about ideal models of social order and the specifics of socio-economic formation at a particular stage of human development. The understanding of the essence of civil society and the assessment of the prospects of its influence on the development of human organization are clarified. It is established that the essence of the partnership between public authorities and territorial communities is due to their existence as a complex process that involves the implementation of mechanisms of mutual control and restrictions. Moreover, the state in this process acts as an entity, not only endowed with power, but also able to delegate them to the institutions of civil society, by endowing territorial communities with the appropriate competence.

Key words: partnership, interaction, civil society, partnership relations, police, territorial communities, state authorities, control, authorities, competence, law-making activity, public organizations, normative legal act.

14. Про добровільне об'єднання територіальних громад: Закон України від 05.02.2015 № 157-VIII. Відомості Верховної Ради. 2015.№ 13. Ст. 91.

15. Про схвалення Концепції реформування місцевого самоврядування та територіальної організації влади в Україні: розпорядження Кабінету Міністрів України №333-р. Обіиійний вісник України. 2014. № 30. Ст. 831.

16. Чикаренко О. Управління стратегічним розвитком об'єднаних територіальних громад: досвід Дніпропетровської області. Науково-практичне забезпечення розвитку та співробітництва об'єднаних територіальних громад : матеріали наук.-практ. конф. за міжнар. участю (30 жовтня - 30 листопада 2018 р.). Дніпро. : ДРІДУ НАДУ, 2018. С. 272-277.

17. Інформація щодо об'єднаних територіальних громад (за даними про проведення чи призначення перших місцевих виборів) https://www.drv.gov.ua/ords/portal/!cm_core.cm_ index?option $=$ ext_gromada\&prejim = 1\&pmn_ id $=149$. 